Wicaksono, F. Y. • A.F. Putri · Y. Yuwariah · Y. Maxiselly · T. Nurmala

\title{
Respons tanaman gandum akibat pemberian sitokinin berbagai konsentrasi dan waktu aplikasi di dataran medium Jatinangor
}

\section{Response of wheat due to various concentrations and application times of cytokinins in moderate elevation Jatinangor}

Diterima : 17 Agustus 2017/Disetujui : 25 Agustus 2017 / Dipublikasikan : 31 Agustus 2017

CDepartment of Crop Science, Padjadjaran University

\begin{abstract}
Growth and yield of wheat (Triticum aestivum L.) can be enhancing by cytokinins application. Cytokinins play a role in delaying senescence of wheat leaves and reducing heat stress in the moderate elevation. The aim of this research was to determine the interaction effect of various cytokinins concentrations and application times on the growth and yield of wheat. The study was conducted in research station Ciparanje, Faculty of Agriculture, Padjadjaran University, Jatinangor, Sumedang from November 2016 until February 2017. The factorial experiment in this research was in a randomized complete block design. The two factors were cytokinins in three levels of concentrations and five levels of application. In which all treatment was repeated 3 times. The results showed that there was an interaction effect on the length of panicles. Besides, the cytokinins concentrations gave single effect on the number of empty grains, while the application times showed the single effect on plant height at 6 weeks after planting (WAP), chlorophyll contents, and number of empty grains. Short-day radiation during the study probably affects to yield and further research can be conducted in ideal length of radiation
\end{abstract}

Keywords: Wheat - Cytokinin • Concentrations · Application times

Sari Pertumbuhan dan hasil gandum (Triticum aestivum L.) diketahui dapat ditingkatkan dengan pemberian sitokinin. Sitokinin berperan juga dalam menunda penuaan daun gandum dan

\footnotetext{
Dikomunikasikan oleh Agus Wahyudin

Wicaksono, F. Y. ${ }^{1}$ A.F. Putri $^{2} \cdot$ Y. Yuwariah ${ }^{1}$ 'Y. Maxiselly ${ }^{1}$

. T. Nurmala ${ }^{1}$

${ }^{1}$ Lecturer at Agriculture Faculty Unpad

2 Bachelor Student at Agriculture Faculty Unpad

Korespondensi: fiky.yulianto@unpad.ac.id
}

mengurangi cekaman panas di dataran medium. Penelitian ini bertujuan untuk mengetahui pengaruh interaksi berbagai konsentrasi sitokinin dengan berbagai waktu aplikasinya terhadap pertumbuhan dan hasil tanaman gandum. Penelitian menggunakan metode percobaan yang dilakukan di kebun percobaan Ciparanje Fakultas Pertanian Universitas Padjadjaran, Jatinangor, Sumedang mulai bulan November 2016 sampai dengan Februari 2017. Rancangan percobaan yang digunakan adalah Rancangan Acak Kelompok, sementara rancangan perlakuan adalah faktorial. Perlakuan terdiri dari dua faktor, yaitu konsentrasi sitokinin (3 taraf) dan waktu aplikasi (5 taraf). Semua perlakuan diulang 3 kali. Hasil penelitian menunjukkan bahwa terdapat pengaruh interaksi pada komponen panjang malai. Faktor konsentrasi sitokinin memberikan pengaruh mandiri pada jumlah gabah hampa, sementara waktu aplikasi memberikan pengaruh mandiri pada tinggi tanaman 6 minggu setelah tanam (MST), kandungan klorofil, dan jumlah gabah hampa. Panjang penyinaran yang pendek selama penelitian menyebabkan hasil tanaman tidak optimal. Penelitian lanjutan dapat dilakukan di panjang penyinaran ideal untuk memvalidasi penelitian ini.

Kata kunci: Gandum • Sitokinin • Konsentrasi • Waktu aplikasi

\section{Pendahuluan}

Gandum (Triticum aestivum L.) merupakan salah satu tanaman serealia dari famili Poaceae. Tanaman ini merupakan bahan baku makanan penting di dunia karena mengandung sumber karbohidrat terbanyak, sama halnya dengan sorgum, jawawut, dan hanjeli. Terigu sebagai olahan biji gandum merupakan bahan baku 
makanan yang tidak asing lagi digunakan di Indonesia. Kebutuhan akan tepung terigu hingga kini menunjukkan perkembangan yang signifikan. Konsumsi tepung terigu di Indonesia pada tahun 2016 meningkat sebesar 7\% (APTINDO, 2016).

Pelonjakan impor gandum Indonesia tercatat sebesar 86,35\% pada bulan Januari 2016 dibandingkan dengan bulan Januari 2015 (BPS, 2016). Departemen Pertanian Amerika Serikat (USDA,2016) memperkirakan impor gandum Indonesia tahun ini mencapai 8,10 juta ton atau naik sekitar $8 \%$ dari tahun sebelumnya $(7,48$ juta ton). Indonesia dengan impor sebanyak itu menjadi importir gandum terbesar nomor dua dunia setelah Mesir (11,50 juta ton). Adanya impor yang besar menyebabkan cadangan devisa berkurang sehingga ketergantungan impor gandum perlu dikurangi. Upaya yang dapat dilakukan diantaranya dengan diversifikasi pangan berbasis pangan lokal atau meningkatkan produktivitas tanaman gandum di Indonesia.

Tanaman gandum merupakan tanaman yang berasal dari daerah subtropis namun dapat tumbuh dan berproduksi dengan baik pada beberapa lahan pertanian di Indonesia, khususnya pada daerah dataran tinggi yang bersuhu rendah (DEPTAN, 1978). Penanaman di dataran tinggi yang masih didominasi oleh tanaman hortikultura dan petani yang relatif belum mengenal tanaman gandum menimbulkan kesulitan penanaman gandum (Puslitbang Tanaman Pangan, 2008). Gandum kemudian diusahakan ditanam di dataran medium untuk menghindari kesulitan tersebut, namun terdapat kendala yang sering dialami di daerah dataran medium yaitu temperatur udara dan temperatur tanah tinggi sehingga tanaman gandum mengalami cekaman panas. Hal ini menyebabkan laju akumulasi pati berkurang yang berpengaruh terhadap hasil tanaman gandum.

Tanaman gandum akan mengalami cekaman panas pada fase akhir pertumbuhan (terminal heat stress atau post anthesis heat stress) (Yang et al., 2002). Pada suhu tinggi laju perkembangan tanaman meningkat sehingga mengurangi potensi akumulasi biomasa. Pengaruh suhu tinggi terhadap perkembangan bulir pada tanaman serealia meliputi laju perkembangan bulir yang lebih cepat, penurunan berat bulir, biji keriput, berkurangnya laju akumulasi pati serta perubahan komposisi lipid dan polipeptida (Stone, 2001).
Sitokinin berfungsi untuk memacu pembelahan sel dalam jaringan meristematik, merangsang diferensiasi sel-sel yang dihasilkan dalam meristem, mendorong pertumbuhan tunas samping, dominasi apikal dan perluasan daun (Mahadi, 2011). Selain itu sitokinin juga berfungsi dalam pembentukan organ dan menunda penuaan daun pada berbagai jenis tanaman (Rakhmawati, 2014). Pemberian sitokinin diharapkan dapat menunda penuaan daun gandum dan mengurangi cekaman panas. Salisburry and Ross (1995) menyatakan sitokinin mampu memperlambat penuaan daun dengan cara mempertahankan keutuhan membran tonoplas, sehingga proses fotosintesis tanaman gandum tidak terganggu yang mengakibatkan aliran fotosintat tetap berjalan dengan baik dan diharapkan akan meningkatkan bobot kering masa total, komponen hasil seperti jumlah malai, panjang malai, jumlah gabah isi, persentase gabah isi, bobot biji, dan indeks panen meningkat.

Johnston and Jeffcoat (1977) menyatakan bahwa pemberian Benzyl Amino Purin pada tanaman gandum dengan konsentrasi 50 ppm, tanaman oat dan barley dengan konsentrasi 100 ppm di fase vegetatif memberikan pengaruh terhadap pertumbuhan, tinggi tanaman, hasil gandum dengan peningkatan $48 \%$, hasil oat dengan peningkatan 26\%, dan hasil barley dengan peningkatan 35\%. Penelitian Sakri $d k k$. (2014) menunjukkan pada pemberian sitokinin dengan konsentrasi 40 ppm meningkatkan panjang daun bendera $17,10 \mathrm{~cm}$ lebih tinggi dibandingkan dengan kontrol, beserta persentasi protein dan karbohidrat yang lebih tinggi dibandingkan dengan kontrol. Menurut Poodineh $d k k$. ., (2013) pemberian sitokinin pada tanaman gandum kultivar Hamoon, memiliki dampak langsung pada proses pertumbuhan dan periode tumbuh gandum akan lebih lama, disebabkan penuaan daun tertunda, sehingga masa pertumbuhan lebih lama. Penyemprotan sitokinin dapat mengurangi kerusakan yang disebabkan karena kekeringan, menghindari penurunan jumlah anakan sekunder, meningkatkan hasil dan biomassa pada tanaman gandum.

Akumulasi perlakuan pemberian hormon pada tanaman terbukti dapat bermanfaat baik terhadap tanaman apabila diaplikasikan pada konsentrasi dan waktu yang tepat. Pemberian zat pengatur tumbuh pada tanaman harus memperhatikan konsentrasi dan waktu aplikasinya. Respons zat pengatur tumbuh akan baik jika diberikan pada konsentrasi yang tepat pada fase 
pertumbuhan tanaman. Umur tana-man gandum yang semakin tua akan menye-babkan semakin kecil konsentrasi sitokinin yang diberikan, karena konsentrasi sitokinin yang diproduksi di dalam tanaman semakin besar (Taiz and Zeiger, 2002). Berdasarkan uraian tersebut, pengaruh interaksi diduga terjadi antara konsentrasi sitokinin dengan waktu aplikasinya terhadap pertumbuhan dan hasil gandum.

\section{Bahan dan Metode}

Penelitian ini dilaksanakan di Kebun Percobaan Fakultas Pertanian, Ciparanje, Universitas Padjadjaran, Jatinangor, Kabupaten Sumedang, Jawa Barat. Ketinggian tempat lokasi penelitian sekitar $750 \mathrm{~m} \mathrm{dpl}$, tipe iklim C3 menurut klasifikasi Oldemann, dengan ordo tanah Inceptisol. Penelitian dilaksanakan mulai bulan November 2016 hingga Februari 2017.

Bahan yang digunakan dalam penelitian ini adalah benih gandum kultivar Dewata, sitokinin sintetik yaitu BAP (Benzyl Amino Purin) dengan beberapa konsentrasi. Sarana produksi yang digunakan adalah pupuk urea, $\mathrm{SP} 36, \mathrm{KCl}$, pupuk silika organik, serta insektisida karbofuran.

Peralatan budidaya yang dibutuhkan mulai dari persiapan lahan hingga panen adalah cangkul, kored, tugal, ember, dan peralatan penunjang lainnya. Selain itu digunakan beberapa peralatan pengamatan di lapangan berupa pulpen, meteran, mistar, klorofil meter, peralatan dokumentasi, oven, timbangan, blender dan komputer. Sarana lain yang digunakan adalah peralatan laboratorium untuk analisis tanah dan peralatan laboratorium pascapanen untuk menganalisis kadar gluten.

Penelitian ini menggunakan metode eksperimen yang dilakukan dalam lingkungan tidak terkendali. Rancangan percobaan adalah Rancangan Acak Kelompok dengan rancangan perlakuan faktorial. Perlakuan terdiri atas dua faktor. Faktor pertama adalah konsentrasi sitokinin yang terdiri dari tiga taraf, yaitu 20 ppm $\left(\mathrm{s}_{1}\right), 40 \mathrm{ppm}\left(\mathrm{s}_{2}\right)$, dan 60 ppm ( $\left.\mathrm{s}_{3}\right)$. Faktor kedua adalah perlakuan waktu aplikasi sitokinin yang terdiri dari lima taraf, yaitu 10 hari setelah tanam (HST; $\left.\mathrm{w}_{1}\right), 25 \mathrm{HST}\left(\mathrm{w}_{2}\right), 40 \mathrm{HST}\left(\mathrm{w}_{3}\right), 55$ HST $\left(w_{4}\right)$, dan 70 HST $\left(w_{5}\right)$ sehingga total perlakuan adalah $3 \times 5=15$ perlakuan. Setiap perlakuan diulang sebanyak 2 kali sehingga terdapat 30 petak percobaan. Ukuran petak percobaan yang digunakan adalah $3 \times 2 \mathrm{~m}$.
Sebelum aplikasi, terlebih dahulu dilakukan kalibrasi untuk menentukan dosisnya. Aplikasi menggunakan sprayer dan disemprotkan pada seluruh daun pada 10 Hari Setelah Tanam (fase pertumbuhan tunas), 25 Hari Setelah Tanam (fase pembentukan anakan), 40 Hari Setelah Tanam (fase akhir vegetatif), 55 Hari Setelah Tanam (fase pembentukan malai), dan 70 Hari Setelah Tanam (fase pemasakan biji).

Pengamatan penunjang dilakukan untuk mengetahui curah hujan, suhu, kelembaban, lama penyinaran, umur berbunga dan umur panen. Pengamatan utama dilakukan untuk mengetahui komponen pertumbuhan, komponen hasil, dan hasil tanaman. Komponen pertumbuhan meliputi tinggi tanaman, jumlah anakan, indeks luas daun, dan kandungan klorofil. Komponen hasil meliputi panjang malai, jumlah gabah hampa, jumlah malai, jumlah biji per malai, bobot 100 biji, dan bobot biji per malai. Pengamatan hasil dan kualitas hasil dilakukan pada bobot biji per tanaman, bobot biji ubinan, dan kadar gluten.

Perbedaan nilai rata-rata taraf suatu faktor pada taraf faktor lain atau perbedaan nilai ratarata suatu taraf pada satu faktor secara mandiri diuji menggunakan Duncan Multiple Range Test pada taraf nyata 5\% (Gasperz, 1995).

\section{Hasil dan Pembahasan}

Pengamatan rata-rata suhu udara selama percobaan adalah sebesar $23,300^{\circ} \mathrm{C}$ dengan ratarata suhu maksimum sebesar $28,4{ }^{\circ} \mathrm{C}$ dan ratarata suhu minimum sebesar $14,1^{\circ} \mathrm{C}$. Suhu udara optimum untuk pertumbuhan tanaman gandum sebesar $15-25{ }^{\circ} \mathrm{C}$. Suhu maksimal di siang hari masih melebihi suhu optimal untuk tanaman gandum sehingga tanaman masih terkena cekaman panas.Rata-rata kelembaban udara dan curah hujan selama masa percobaan masingmasing sebesar $90 \%$ dan $7,3 \mathrm{~mm} /$ bulan. Kelembaban udara pada masa percobaan dapat dikatakan optimum karena kelembaban yang baik untuk tanaman gandum adalah $90 \%$ pada saat musim hujan dan $80 \%$ pada saat musim kemarau, sedangkan untuk curah hujan optimum untuk tanaman gandum di Indonesia yaitu berkisar antara 1.500-2.000 mm/tahun (Nurmala dan Irwan. 2007). Panjang penyinaran matahari selama masa percobaan sebesar $49 \%$ (< 4 jam) yang berarti tanaman gandum sangat 
sedikit mendapatkan cahaya matahari. Tanaman gandum subtropik termasuk dalam long day plant. Pada kenyataannya, tanaman gandum yang ditanam selama penelitian tetap berbunga meskipun hari pendek (12 jam). Hal ini diduga bahwa varietas gandum yang ditanam saat penelitian termasuk kedalam tanaman short day plant karena mampu berbunga pada panjang penyinaran kurang dari 12 jam.

Panjang penyinaran juga berdampak pada umur berbunga dan umur panen. Umur berbunga dan umur panen pada percobaan ini lebih cepat dibandingkan deskripsi varietas dan penelitian sebelumnya. Tanaman gandum pada percobaan ini mulai berbunga pada 55 HST dan panen pada $90 \mathrm{HST}$, sementara menurut deskripsi varietas Dewata, tanaman berbunga pada umur 70 HST dan panen pada 110 HST. Beberapa penelitian sebelumnya mencatat panen gandum dapat mencapai umur 130 HST di dataran medium (Wicaksono et.al., 2016).

Tabel 1. Pengaruh Mandiri Konsentrasi Hormon Sitokinin dan Waktu Aplikasi terhadap Tinggi Tanaman dan Jumlah Anakan Gandum Kultivar Dewata pada 6 MST.

\begin{tabular}{|c|c|c|}
\hline Perlakuan & $\begin{array}{c}\text { Tinggi } \\
\text { Tanaman }(\mathrm{cm})\end{array}$ & $\begin{array}{l}\text { Jumlah } \\
\text { Anakan }\end{array}$ \\
\hline \multicolumn{3}{|c|}{ Konsentrasi Sitokinin (s) : } \\
\hline $\mathrm{s}_{1}(20 \mathrm{ppm})$ & 33,34 a & 2,14 a \\
\hline $\mathrm{s}_{2}(40 \mathrm{ppm})$ & 35,14 a & 2,32 a \\
\hline $\mathrm{s}_{3}(60 \mathrm{ppm})$ & 34,77 a & 1,90 a \\
\hline \multicolumn{3}{|c|}{ Waktu Aplikasi (w) } \\
\hline $\mathrm{w}_{1}(10 \mathrm{HST})$ & $47,11 \mathrm{~b}$ & 2,89 a \\
\hline $\mathrm{w}_{2}(25 \mathrm{HST})$ & $45,80 \mathrm{ab}$ & 2,80 a \\
\hline $\mathrm{w}_{3}(40 \mathrm{HST})$ & 44,75 a & 2,80 a \\
\hline
\end{tabular}

Keterangan: Nilai rata-rata yang diikuti oleh huruf yang sama tidak berbeda nyata menurut Uji Jarak Berganda Duncan pada taraf $5 \%$.

Analisis sidik ragam mengenai tinggi tanaman dan jumlah anakan gandum 6 MST menunjukkan tidak terdapat interaksi antara konsentrasi sitokinin dengan waktu aplikasi terhadap tinggi tanaman dan jumlah anakan 6 MST. Tabel 1 menunjukkan bahwa taraf waktu aplikasi $\mathrm{w}_{1}$ (10 HST) berbeda nyata dengan $\mathrm{w}_{3}$ (40 HST), namun tidak berbeda nyata dengan perlakuan $\mathrm{w}_{2}$ (25 HST) terhadap tinggi tanaman gandum pada 6 MST. Hal ini disebabkan pada umur 6 MST tanaman gandum masih aktif melakukan pembelahan sel, sehingga pemberian sitokinin pada masa waktu tersebut efektif untuk meningkatkan tinggi tanaman gandum (Salisbury dan Ross, 1995).
Jumlah anakan pada umur 6 MST tidak dipengaruhi baik oleh konsentrasi hormon sitokinin maupun waktu aplikasi yang berbeda. Hal ini disebabkan panjang penyinaran matahari hanya $49 \%$ (< 4 jam) yang menyebabkan proses fotosintesis tanaman gandum kurang optimum sehingga berpengaruh terhadap pembentukan anakan yang menghasilkan anakan yang sedikit.

Analisis sidik ragam menunjukkan tidak terdapat interaksi antara konsentrasi sitokinin dengan waktu aplikasi terhadap indeks luas daun dan kandungan klorofil. Hasil uji analisis menunjukkan bahwa pemberian konsentrasi sitokinin dengan waktu aplikasi berbeda terhadap komponen indeks luas daun tidak menunjukkan adanya perbedaan yang nyata, namun pada komponen kandungan klorofil menunjukkan adanya perbedaan yang nyata pada taraf waktu aplikasi $\mathrm{w}_{3}$ (40 HST) dibandingkan dengan $\mathrm{w}_{1}$ (10 HST) dan $\mathrm{w}_{4}$ (55 HST). Konsentrasi sitokinin secara mandiri tidak berpengaruh terhadap indeks luas daun dan klorofil (Tabel 2).

Tabel 2. Pengaruh Mandiri Konsentrasi Hormon Sitokinin dan Waktu Aplikasi terhadap Indeks Luas Daun dan Kandungan Klorofil Tanaman Gandum Kultivar Dewata pada 8 MST.

\begin{tabular}{lcc}
\hline Perlakuan & $\begin{array}{c}\text { Indeks Luas } \\
\text { Daun }\end{array}$ & $\begin{array}{c}\text { Kandungan } \\
\text { Klorofil }\end{array}$ \\
\hline Konsentrasi Sitokinin (s) : & \\
$\mathrm{s}_{1}(20 \mathrm{ppm})$ & $3,01 \mathrm{a}$ & $35,76 \mathrm{a}$ \\
$\mathrm{s}_{2}(40 \mathrm{ppm})$ & $2,98 \mathrm{a}$ & $36,67 \mathrm{a}$ \\
$\mathrm{s}_{3}(60 \mathrm{ppm})$ & $2,99 \mathrm{a}$ & $37,59 \mathrm{a}$ \\
Waktu Aplikasi $(\mathrm{w})$ & & \\
$\mathrm{w}_{1}(10 \mathrm{HST})$ & $2,83 \mathrm{a}$ & $36,36 \mathrm{a}$ \\
$\mathrm{w}_{2}(25 \mathrm{HST})$ & $2,92 \mathrm{a}$ & $36,76 \mathrm{ab}$ \\
$\mathrm{w}_{3}(40 \mathrm{HST})$ & $3,38 \mathrm{a}$ & $37,54 \mathrm{~b}$ \\
$\mathrm{w}_{4}(55 \mathrm{HST})$ & $2,84 \mathrm{a}$ & $36,04 \mathrm{a}$ \\
\hline \hline
\end{tabular}

Keterangan: Nilai rata-rata yang diikuti oleh huruf yang sama tidak berbeda nyata menurut Uji Jarak Berganda Duncan pada taraf 5\%.

Rendahnya nilai indeks luas daun diduga karena intensitas cahaya matahari yang kurang selama penanaman, hal ini dikarenakan curah hujan yang tinggi pada saat penanaman. Intensitas cahaya matahari sangat mempengaruhi pertumbuhan optimum tanaman dengan indeks luas daun yang berbeda-beda tergantung tinggi tanaman dan banyaknya sinar matahari yang diterima oleh tanaman tersebut (Gardner et al., 1991). Kandungan klorofil yang tinggi pada saat 40 HST diduga tanaman telah menyerap hormon 
sitokinin dengan baik jika dibandingkan dengan umur 10 HST dan 55 HST karena pada saat umut 10 HST tanaman belum dapat menyerap hormon dengan baik, sedangkan pada umur 55 HST tanaman gandum baru mendapat perlakuan penyemprotan sitokinin sehingga belum memberikan efek yang nyata terhadap kandungan klorofil, selain itu salah satu fungsi hormon sitokinin adalah dapat memicu peningkatan kadar klorofil melalui stimulasi sintesis klorofil. Sintesis klorofil dipengaruhi oleh berbagai faktor seperti cahaya, gula atau karbohidrat, air, temperatur, faktor genetik, unsur-unsur hara seperti $\mathrm{N}, \mathrm{Mg}, \mathrm{Fe}, \mathrm{Mn}$, $\mathrm{Cu}, \mathrm{Zn}, \mathrm{S}$ dan O (Hendriyani dan Setiari, 2009). Klorofil merupakan faktor utama dalam proses fotosintesis.

Terdapat interaksi antara konsentrasi sitokinin dengan waktu aplikasi berbeda terhadap panjang malai berdasarkan hasil analisis ragam. Pemberian konsentrasi sitokinin yang lebih tinggi sampai 40 ppm hanya terjadi pada taraf 10 HST. Pada taraf 10 HST, pemberian konsentrasi sitokinin 40 ppm lebih baik dibandingkan konsentrasi $20 \mathrm{ppm}$, tetapi tidak berbeda nyata dengan konsentrasi $60 \mathrm{ppm}$. Semakin lama waktu aplikasi menyebabkan konsentrasi sitokinin dapat dikurangi. Hal ini dapat dilihat pada taraf waktu aplikasi 25, 55, dan 70 HST dimana antar taraf konsentrasi tidak memberikan perbedaan yang nyata. Pada taraf waktu aplikasi 40 HST, konsentrasi sitokinin 20 ppm bahkan memberikan panjang malai yang lebih baik dibandingkan konsentrasi $40 \mathrm{ppm}$ dan tidak berbeda nyata dengan konsentrasi 60 ppm (Tabel 3).

Tabel 3. Pengaruh Interaksi Konsentrasi Hormon Sitokinin dan Waktu Aplikasi Berbeda terhadap Panjang Malai Tanaman Gandum Kultivar Dewata.

\begin{tabular}{|c|c|c|c|c|c|}
\hline \multirow{2}{*}{$\begin{array}{l}\text { Konsentrasi } \\
\text { Sitokinin (s) }\end{array}$} & \multicolumn{5}{|c|}{ Waktu Aplikasi (w) } \\
\hline & $\begin{array}{c}\mathrm{W}_{1} \\
(10 \mathrm{HST})\end{array}$ & $\begin{array}{c}\mathrm{W}_{2} \\
\text { (25 HST) }\end{array}$ & $\begin{array}{c}\mathrm{W}_{3} \\
(40 \mathrm{HST})\end{array}$ & $\begin{array}{c}\mathrm{W}_{4} \\
\text { (55 HST) }\end{array}$ & $\begin{array}{c}\mathrm{W}_{5} \\
(70 \mathrm{HST})\end{array}$ \\
\hline $\mathrm{s}_{1}(20 \mathrm{ppm})$ & $\begin{array}{c}6,92 \mathrm{a} \\
\mathrm{A}\end{array}$ & $\begin{array}{c}7,26 \mathrm{a} \\
\mathrm{A}\end{array}$ & $\begin{array}{c}7,30 \mathrm{~b} \\
\mathrm{~A}\end{array}$ & $\begin{array}{c}7,23 \mathrm{a} \\
\mathrm{A}\end{array}$ & $\begin{array}{c}7,28 \mathrm{a} \\
\mathrm{A}\end{array}$ \\
\hline $\mathrm{s}_{2}(40 \mathrm{ppm})$ & $\begin{array}{c}7,42 \mathrm{~b} \\
\mathrm{~B}\end{array}$ & $\begin{array}{c}6,85 \mathrm{a} \\
\mathrm{A}\end{array}$ & $\begin{array}{c}6,69 a \\
\text { A }\end{array}$ & $\begin{array}{c}7,08 \mathrm{a} \\
\mathrm{AB}\end{array}$ & $\begin{array}{c}7,44 \mathrm{a} \\
\text { B }\end{array}$ \\
\hline $\mathrm{s}_{3}(60 \mathrm{ppm})$ & $\begin{array}{c}6,94 \mathrm{ab} \\
\mathrm{A}\end{array}$ & $\begin{array}{c}7,23 \text { a } \\
\mathrm{AB}\end{array}$ & $\begin{array}{c}7,00 \mathrm{ab} \\
\mathrm{A}\end{array}$ & $\begin{array}{c}7,19 \mathrm{a} \\
\mathrm{AB}\end{array}$ & $\begin{array}{c}7,62 \mathrm{a} \\
\mathrm{B}\end{array}$ \\
\hline
\end{tabular}

Keterangan : Nilai rata-rata yang ditandai oleh huruf kecil yang sama (arah verikal) dan huruf kapital yang sama (arah horizontal) tidak berbeda nyata menurut menurut Uji Jarak Berganda Duncan pada taraf 5\%.

Panjang malai merupakan parameter yang menentukan tinggi rendahnya produktivitas suatu galur/varietas. Panjang malai berkorelasi erat kaitannya dengan tinggi tanaman dan berpengaruh terhadap produksi. Hormon sitokinin mampu meningkatkan panjang malai gandum, hal ini disebabkan karena secara umum sitokinin dapat mempengaruhi pertumbuhan, pengaturan pembelahan sel, dan pemanjangan sel maka dari itu pemberian sitokinin mampu meningkatkan panjang malai tanaman gandum.

Tidak terdapat interaksi antara konsentrasi hormon sitokinin dan waktu aplikasi berbeda terhadap jumlah gabah hampa per malai berdasarkan hasil analisis ragam. Pada komponen jumlah gabah hampa menunjukkan adanya perbedaan yang nyata pada pengaruh mandiri konsentrasi sitokinin dan faktor waktu aplikasi (Tabel 4). Semakin tinggi konsentrasi menyebabkan jumlah gabah hampa menjadi sedikit. Waktu aplikasi 70 HST lebih banyak menghasilkan gabah hampa dibandingkan waktu aplikasi $25 \mathrm{HST}$, tetapi tidak berbeda nyata dengan taraf waktu aplikasi 10, 40, dan 55 HST. Hal ini diperkuat bahwa sitokinin dapat memperbesar peluang pembentukan biji (Taiz dan Zeiger, 2002). Konsentrasi sitokinin yang lebih tinggi dapat meningkatkan jumlah gabah isi dan menekan jumlah gabah hampa. Waktu aplikasi sitokinin setelah berbunga ternyata menghasilkan jumlah gabah hampa yang lebih banyak. Hal ini harus diteliti lebih lanjut, apakah jumlah gabah hampa memang benar meningkat akibat aplikasi sitokinin setelah berbunga.

Tabel 4. Pengaruh Mandiri Konsentrasi Hormon Sitokinin dan Waktu Aplikasi Berbeda terhadap Jumlah Gabah Hampa per Malai Kultivar Dewata.

\begin{tabular}{|c|c|}
\hline Perlakuan & $\begin{array}{c}\text { Jumlah Gabah Hampa } \\
\text { per Malai (bulir) }\end{array}$ \\
\hline \multicolumn{2}{|c|}{ Konsentrasi Sitokinin (s) : } \\
\hline $\mathrm{s}_{1}(20 \mathrm{ppm})$ & $12,98 \mathrm{~b}$ \\
\hline $\mathrm{s}_{2}(40 \mathrm{ppm})$ & 9,41 a \\
\hline $\mathrm{s}_{3}(60 \mathrm{ppm})$ & $10,71 \mathrm{a}$ \\
\hline \multicolumn{2}{|c|}{ Waktu Aplikasi (w) } \\
\hline $\mathrm{w}_{1}(10 \mathrm{HST})$ & $10,58 \mathrm{ab}$ \\
\hline $\mathrm{w}_{2}(25 \mathrm{HST})$ & 9,60 a \\
\hline $\mathrm{w}_{3}(40 \mathrm{HST})$ & $10,96 \mathrm{ab}$ \\
\hline $\mathrm{w}_{4}(55 \mathrm{HST})$ & $10,87 \mathrm{ab}$ \\
\hline $\mathrm{w}_{5}(70 \mathrm{HST})$ & $13,16 \mathrm{~b}$ \\
\hline
\end{tabular}

Keterangan: Nilai rata-rata yang diikuti oleh huruf yang sama tidak berbeda nyata menurut Uji Jarak Berganda Duncan pada taraf $5 \%$.

Tidak terdapat interaksi antara konsentrasi sitokinin dengan waktu aplikasi terhadap jumlah malai per rumpun, jumlah gabah isi per 
malai, bobot biji per malai, dan bobot 100 butir berdasarkan hasil analisis ragam (Tabel 5). Pengaruh interaksi juga tidak terdapat pada bobot biji per rumpun, bobot biji per petak, indeks panen, dan kadar gluten (Tabel 6).

Tabel 5. Pengaruh Mandiri Konsentrasi Hormon Sitokinin dan Waktu Aplikasi terhadap Jumlah Malai per Rumpun, Jumlah Gabah isi per Malai, Bobot Biji per Malai, dan Bobot 100 Butir Tanaman Gandum Kultivar Dewata.

\begin{tabular}{|c|c|c|c|c|}
\hline Perlakuan & $\begin{array}{l}\text { Jumlah } \\
\text { Malai } \\
\text { per } \\
\text { Rumpun }\end{array}$ & $\begin{array}{l}\text { Jumlah } \\
\text { Gabah } \\
\text { Isi per } \\
\text { Malai } \\
\text { (bulir) }\end{array}$ & $\begin{array}{c}\text { Bobot } \\
\text { Biji per } \\
\text { Malai (g) }\end{array}$ & $\begin{array}{c}\text { Bobot } \\
100 \text { Butir } \\
\text { (g) }\end{array}$ \\
\hline \multicolumn{5}{|c|}{ Konsentrasi Sitokinin (s) : } \\
\hline $\mathrm{s}_{1}(20 \mathrm{ppm})$ & $3,00 \mathrm{a}$ & $16,37 \mathrm{a}$ & $0,40 \mathrm{a}$ & $2,71 \mathrm{a}$ \\
\hline $\mathrm{s}_{2}(40 \mathrm{ppm})$ & $3,16 \mathrm{a}$ & 17,44 a & $0,40 \mathrm{a}$ & $2,78 \mathrm{a}$ \\
\hline $\mathrm{s}_{3}(60 \mathrm{ppm})$ & $2,93 \mathrm{a}$ & 17,43 a & $0,41 \mathrm{a}$ & $2,75 \mathrm{a}$ \\
\hline \multicolumn{5}{|c|}{ Waktu Aplikasi (w) } \\
\hline $\mathrm{w}_{1}(10 \mathrm{HST})$ & $3,19 \mathrm{a}$ & 16,59 a & $0,40 \mathrm{a}$ & $2,69 \mathrm{a}$ \\
\hline $\mathrm{w}_{2}(25 \mathrm{HST})$ & $2,81 \mathrm{a}$ & 16,59 a & $0,43 \mathrm{a}$ & $2,76 \mathrm{a}$ \\
\hline $\mathrm{w}_{3}(40 \mathrm{HST})$ & $2,48 \mathrm{a}$ & $18,20 \mathrm{a}$ & $0,40 \mathrm{a}$ & $2,74 \mathrm{a}$ \\
\hline $\mathrm{w}_{4}(55 \mathrm{HST})$ & $3,35 \mathrm{a}$ & $17,32 \mathrm{a}$ & $0,37 \mathrm{a}$ & $2,75 \mathrm{a}$ \\
\hline w5 (70 HST) & $3,32 \mathrm{a}$ & 16,71 a & $0,41 \mathrm{a}$ & $2,79 \mathrm{a}$ \\
\hline
\end{tabular}

Keterangan: Nilai rata-rata yang diikuti oleh huruf yang sama tidak berbeda nyata menurut Uji Jarak Berganda Duncan pada taraf 5\%.

Tabel 6. Pengaruh Mandiri Konsentrasi Hormon Sitokinin dan Waktu Aplikasi terhadap Jumlah Malai per Rumpun, Jumlah Gabah isi per Malai, Bobot Biji per Malai, dan Bobot 100 Butir Tanaman Gandum Kultivar Dewata.

\begin{tabular}{|c|c|c|c|c|}
\hline Perlakuan & $\begin{array}{l}\text { Bobot Biji } \\
\text { per Rum- } \\
\text { pun (g) }\end{array}$ & $\begin{array}{c}\text { Bobot } \\
\text { Biji per } \\
\text { Petak }(\mathrm{g})\end{array}$ & $\begin{array}{l}\text { Indeks } \\
\text { Panen }\end{array}$ & $\begin{array}{l}\text { Kadar } \\
\text { Gluten } \\
(\%)\end{array}$ \\
\hline \multicolumn{5}{|l|}{ Konsentrasi } \\
\hline \multicolumn{5}{|l|}{ Sitokinin (s) } \\
\hline $\mathrm{s}_{1}(20 \mathrm{ppm})$ & 1,14 a & 94,14 a & $0,26 a$ & 13,01 \\
\hline $\mathrm{s}_{2}(40 \mathrm{ppm})$ & $1,35 \mathrm{a}$ & $96,12 \mathrm{a}$ & $0,33 \mathrm{a}$ & 13,16 \\
\hline $\mathrm{s}_{3}(60 \mathrm{ppm})$ & $1,18 \mathrm{a}$ & $83,27 \mathrm{a}$ & $0,35 \mathrm{a}$ & 11,86 \\
\hline \multicolumn{5}{|l|}{ Waktu } \\
\hline \multicolumn{5}{|l|}{ Aplikasi (w) } \\
\hline $\mathrm{w}_{1}(10 \mathrm{HST})$ & $1,29 \mathrm{a}$ & 81,47 a & $0,30 \mathrm{a}$ & 14,04 \\
\hline $\mathrm{w}_{2}(25 \mathrm{HST})$ & $1,16 \mathrm{a}$ & 89,03 a & $0,33 \mathrm{a}$ & 12,74 \\
\hline $\mathrm{w}_{3}(40 \mathrm{HST})$ & $0,92 \mathrm{a}$ & $100,64 \mathrm{a}$ & $0,29 \mathrm{a}$ & 12,44 \\
\hline $\mathrm{w}_{4}(55 \mathrm{HST})$ & $1,44 \mathrm{a}$ & 99,74 a & $0,38 \mathrm{a}$ & 12,47 \\
\hline $\mathrm{w}_{5}$ (70 HST) & $1,32 \mathrm{a}$ & 84,99 a & $0,27 \mathrm{a}$ & 11,67 \\
\hline
\end{tabular}

Keterangan: Nilai rata-rata yang diikuti oleh huruf yang sama tidak berbeda nyata menurut Uji Jarak Berganda Duncan pada taraf 5\%.

Tidak adanya perbedaan yang nyata yang diberikan oleh pengaruh mandiri konsentrasi sitokinin maupun waktu aplikasinya menunjukkan sitokinin tidak banyak berpengaruh pada komponen hasil dan hasil. Sitokinin hanya mempengaruhi panjang malai saja. Faktor penyinaran matahari yang kurang dari 8 jam juga dapat mempengaruhi kerja sitokinin, sehingga perlu penelitian lanjutan dengan panjang penyinaran $100 \%$ untuk melihat kerja dari sitokinin tersebut.

\section{Kesimpulan}

Terdapat pengaruh interaksi hanya pada komponen panjang malai. Faktor konsentrasi sitokinin memberikan pengaruh mandiri pada jumlah gabah hampa, sementara waktu aplikasi memberikan pengaruh mandiri pada tinggi tanaman 6 minggu setelah tanam (MST), kandungan klorofil, dan jumlah gabah hampa. Penelitian lanjutan dapat dilakukan di panjang penyinaran ideal untuk memvalidasi penelitian ini.

\section{Daftar Pustaka}

APTINDO. 2016. Indonesian Wheat Flour Consumption.

http://aptindo.or.id/overview/(Diakses pada 24 Maret 2017 pukul 21:14).

Badan Pusat Statistik (BPS). 2016. Data impor gandum 2016. Tersedia online: http://www.bps.go.id/. Diakses pada 22 September 2016.

DEPTAN. 1978. Laporan Hasil Survei Potensi Tanaman Gandum. Bidang Potensi Tegakan gandum (konsep).

Gardner, F.P, R.B. Pearce, and R.L. Mitchel. 1991. Fisiologi Tanaman Budidaya. Penerjemah Herawti Susilo. UI-Press. Jakarta.

Gasperz, V. 1995. Teknik Analisis dalam Penelitian Percobaan Edisi 1. Penerbit Tarsito. Bandung.

Hendriyani, I. S dan N. Setiari. 2009. Dalam Ai, Nio Song dan Yunia Banyo. 2011. Konsentrasi Klorofil Daun Sebagai Indikator Kekurangan Air Pada Tanaman. Jurnal Ilmiah Sains Vol. 11 No. 2. PS Biologi FMIPA Universitas Sam Ratulangi, Manado.

Johnston, G. F. and Jeffcoat, B. 1977. Effect of some growth regulators on tiller bud elongation in cereals. New Phytol. 79: 239 245.

Mahadi, I. 2011. Pematahan Dormansi Biji Kenerak (Goniothalamus umbrosusu) Menggunakan hormon 2,4-D dan BAP 
Secara Mikropropagasi. Sagu. Maret 2011. Vol.10 No.1:20-23.

Poodineh, Ahmad Mehraban, dan Hosein A. 2014. Effect of Water Stress and Spraying Cytokinin Hormone on Hamoon Wheat Variety in Sistan Region. International Journal of Farming and Allied Sciences. Vol. 4 (S4), pp. 814-818.

Puslitbang Tanaman Pangan. 2008. Prospek dan Arah Pengembangan Agribisnis Gandum. Bogor.

Rakhmawati, D. A. 2014. Kajian Sitokinin (CPPU) Terhadap Pertumbuha dan Perkembangan Dua Sumber Bibit Bulbil Tanaman Poran (Amorphophallus onchophyllus). Skripsi Fakultas Pertanian Universitas Pembangunan Nasional "Veteran" Jawa Timur, Surabaya.

Sakri., A. Faisal, dan S. A. Amin. 2009. The Response of two Wheat Cultivars Triticum spp to Cytokinin and Water Stress Treatments and their Interaction. Journal of Zankoy Sulaimani. No.1, Vol 12, pp. 51-58.
Salisbury, F.B. dan C.W. Ross. 1995. Fisiologi Tumbuhan, Biokimia Tumbuhan, jilid 2. Penerjemah: Lukman, D.R. dan Sumaryono. Penerbit ITB, Bandung.

Stone, P. 2001. The effects of heat stress on cereal yield and quality. In: Basra, A.S. (Ed.). Crop Responses and Adaptation to Temperature Stress. Food Products Press, Binghamton, NY, pp. 243-291.

Taiz, L. dan E. Zeiger. 2002. Plant Physiology, $3^{\text {rd }}$ Ed. Sinauer Associates Sunderland.

United States Departement of Agriculture (USDA). 2016. Indonesia: Grain and feed update. Tersedia online: http://www. fas.usda.gov/. Diakses 22 September 2016

Wicaksono, F. Y., T. Nurmala, A.W. Irwan, dan A.S.U. Putri. 2016. Pengaruh Pemberian Gibberellin dan Sitokinin pada Konsentrasi yang Berbeda terhadap Pertumbuhan dan Hasil Gandum (Triticum aestivum L.) di Dataran Medium Jatinangor. J. Kultivasi Vol. 15 (1). 